\title{
BAHASA ADANG DI PULAU ALOR: KAJIAN VITALITAS ETNOLINGUISTIK
}

Adang in Alor Island: The Study of Ethnolinguistics Vitality

\author{
Inayatusshalihah $^{1}$ dan Miranti Sudarmaji $^{2}$ \\ 1,2Badan Pengembangan dan Pembinaan Bahasa \\ inayatusshalihah@kemdikbud.go.id
}

Naskah Diterima Tanggal 11 Januari 2020—Direvisi Akhir Tanggal 30 Oktober 2020—Disetujui Tanggal 28 November 2020 doi: https://doi.org/10.26499/rnh.v9i2.2933

\begin{abstract}
Abstrak
Kajian ini bertujuan untuk mengukur tingkat daya hidup bahasa Adang di Adang Buom, Kecamatan Teluk Mutiara, Kabupaten Alor berdasarkan indikator ranah penggunaan bahasa. Dengan teori vitalitas etnolinguistik, penggunaan bahasa Adang dilihat dalam lima ranah, yaitu rumah, ibadah, transaksi, pendidikan, dan institusi pemerintahan dan kesehatan. Data kajian berupa data primer yang diperoleh melalui kuesioner dan data sekunder dari penelusuran pustaka. Data primer diolah secara statistik deskriptif dengan penghitungan frekuensi dan persentase tiap pernyataan yang berkaitan dengan penggunaan bahasa. Hasil kajian berdasarkan analisis persentase data kuesioner menunjukkan jumlah ranah penggunaan bahasa Adang dalam komunitas tutur Adang Buom mengalami penyusutan. Bahasa Adang digunakan bersamaan dengan penggunaan bahasa Indonesia (Melayu-Alor), baik di ranah yang bersifat pribadi maupun umum. Generasi muda cenderung menggunakan bahasa Indonesia (Melayu-Alor) di rumah dengan keluarga. Oleh karena itu, bahasa Adang dapat dikategorikan sebagai bahasa dengan vitalitas etnolinguistik yang rendah berdasarkan indikator ranah penggunaan.
\end{abstract}

Kata-kata kunci: bahasa Adang, vitalitas etnolinguistik, penggunaan bahasa, ranah

\begin{abstract}
This study aims to examine the vitality of Adang language in Adang Buom, Teluk Mutiara District, Alor Regency based on indicator of language use. With framework of ethnolinguistic vitality theory, the use of Adang is observed in five domains such as home, religion, transaction, education, government and health institution. Data in this study consists of primary data which obtained through questionnaire and secondary data acquired through literature review. The primary data was processed statistically descriptive by calculating the frequency and percentage of each statement related to language use. The result shows the number of Adang domains amongst Adang Buom community has decreased. Adang is used in conjuction with Indonesian (or Malay-alor), both in private and public domains. The young generation tends to use Indonesian (or Malay-Alor) in home domain. Based on the indicator of language use, Adang in Adang Buom community could be categorized as a language with low ethnolinguistic vitality.
\end{abstract}

Keywords: Adang language, ethnolinguistic vitality, language use, domain

How to Cite: Inayatusshalihah dan Miranti Sudarmaji. (2020). Bahasa Adang di Pulau Alor: Kajian Vitalitas Etnolinguistik. Ranah: Jurnal Kajian Bahasa. 9(2). 212-230. doi: https://doi.org/10.26499/rnh.v9i2.2933 


\section{PENDAHULUAN}

Vitalitas bahasa dibentuk oleh serangkaian faktor seperti kebijakan terkait status yang diberikan kepada budaya dan bahasa, sikap penutur terhadap bahasa dan budayanya, dan ranah penggunaan bahasa dengan penekanan pada penggunaan di rumah dan sekolah lokal (Hirsh, 2013). Bahasa-bahasa daerah di Indonesia sebagian besar dapat dikatakan tidak memenuhi faktor pembentuk vitalitas yang disebutkan Hirsh (2013), terutama bahasa di wilayah Indonesia bagian timur. Oleh karena itu, wajar jika dikatakan bahasa-bahasa daerah di Indonesia bagian timur termasuk bahasa yang paling terancam punah.

Tulisan ini bertujuan untuk melihat vitalitas etnolinguistik bahasa Adang di Pulau Alor, Nusa Tenggara Timur. Bahasa Adang merupakan salah satu bahasa di Pulau Alor, wilayah Indonesia bagian timur. Bahasa ini termasuk bahasa Papua, yakni kelompok Alor-Pantar, Trans New Guinea (non-Austronesia). Bahasa Adang sering disamakan dengan bahasa Kabola, tetapi beberapa kajian menganggap Adang sebagai bahasa yang berbeda dari Kabola karena adanya perbedaan fonologis.

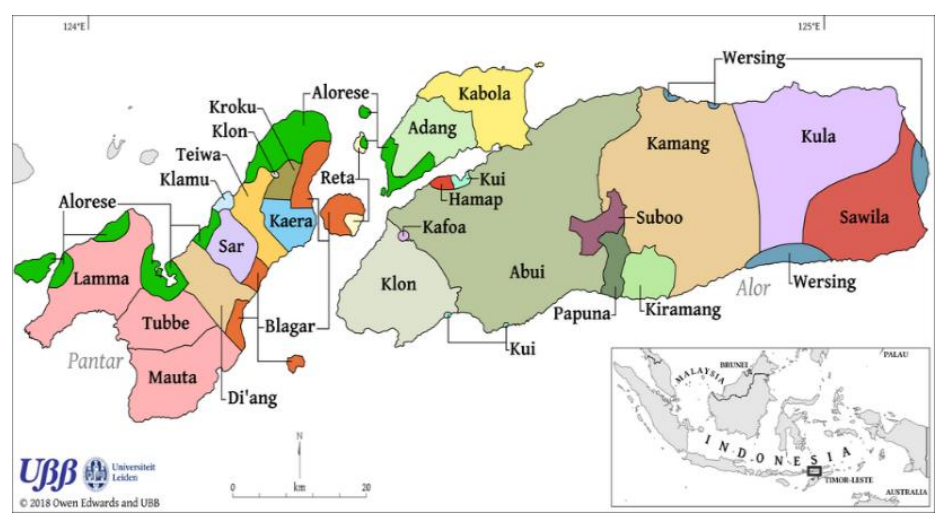

Gambar 1. Bahasa di Alor dan Pantar

Sumber: vici.marianklamer.org/linguistic-maps.html

Penutur bahasa Adang dapat ditemukan di Desa Adang-Buom, Adang-Kokar, Pitungbang (Otvai), Kenalirang, Afeng Male, Oa'mate, Aimoli, Bot Bag, Bu Mol, dan Alila. Bahasa Adang memiliki sekitar 7.000 penutur yang tinggal di desa-desa sekitar ibu kota Kabupaten Alor, Kalabahi. Sepanjang wilayah pesisir sampai bagian barat Kalabahi, penutur bahasa Adang bercampur dengan penutur bahasa Alor, Pura (Blagar), dan Reta (Haan, 2001). Ethnologue menyebut Adang sebagai bahasa yang mempunyai populasi penutur yang kecil (< 10.000 penutur) dan berada pada level EGIDS 6b 'threatened' karena tidak dipelajari dan digunakan lagi oleh anak-anak (Eberhard et al., 2000). 
Salah satu wilayah tutur bahasa Adang di Alor adalah Desa Adang Buom yang menjadi lokasi kajian ini. Desa ini terletak di bagian barat Kalabahi dan termasuk wilayah administrasi Kecamatan Teluk Mutiara, Kabupaten Alor. Luas Desa Adang Buom 0,87 km², berjarak sekitar 1,3 km dari ibu kota kecamatan dan 7,7 km dari ibu kota kabupaten. Jumlah penduduk 1.697 jiwa, yakni 3,26\% dari jumlah penduduk Kecamatan Teluk Mutiara (BPS Kabupaten Alor, 2019). Menurut penjelasan Berimau (2018), Adang Buom merupakan desa baru yang terbentuk akibat migrasi masyarakat Adang dari Kampung Lama. Migrasi tersebut disebabkan oleh penataan administrasi tahun 1956 yang menetapkan Kampung Lama Adang sebagai daerah kehutanan. Sebelumnya, wilayah Adang dibagi menjadi tiga, yaitu Adang, Pitung Bang, dan O'amate-Emoil. Migrasi juga disebabkan kebakaran yang terjadi di Kampung Lama pada tahun 1958 .

Penelitian mengenai bahasa-bahasa Alor-Pantar sudah pernah dilakukan. Akan tetapi, penelitian yang memfokuskan pembahasannya pada vitalitas bahasa-bahasa Alor-Pantar belum banyak dilakukan. Tondo (2007) mengkaji bahasa Hamap dalam masyarakat multibahasa di Alor dan upaya pelestariannya. Bahasa Hamap dinyatakan mengalami pergeseran pemakaian karena banyak generasi muda Hamap cenderung menggunakan bahasa Melayu Alor dalam komunikasi sehari-hari sehingga berpotensi terancam punah. Sementara itu, Probonegoro (2008) mengkaji perubahan identitas etnolinguistik penutur bahasa Hamap. Ia memaparkan mitologi Hamap yang berkaitan dengan migrasi nenek moyang dan leluhur Hamap yang berkembang menjadi kelompok etnis Adang, Kabola, Mor, Pura, dan Abui. Masih mengenai bahasa Hamap, Adhiti (2020) mengkaji sinonimi bahasa Hamap dan Kabola. Hasil analisis menunjukkan kosakata bahasa Hamap dan Kabola memiliki kesamaan/ kemiripan bentuk yang dikelompokkan menjadi (1) sinonimi dengan penambahan fonem vokal dan konsonan pada posisi depan dan belakang kata, (2) sinonimi dengan pertalian fonem vokal dan konsonan pada posisi tengah dan belakang kata, (3) sinonimi dengan pertalian, penambahan, dan penghilangan suku kata pada suku kata pertama dan kedua, dan (4) sinonimi dengan bentuk atau berian mutlak sama.

Haan (2001) dalam disertasinya yang berjudul The Grammar of Adang membicarakan kondisi daya hidup bahasa Adang di bagian pendahuluan. Ia menyebutkan bahwa bahasa Adang berpotensi terancam punah terutama karena penuturnya tinggal di desa-desa sekitar Kalabahi, tempat bahasa Indonesia digunakan secara luas. Generasi muda penutur Adang cenderung menggunakan bahasa Indonesia daripada bahasa jatinya. Orang tua pun cenderung mengajarkan bahasa Indonesia kepada anak-anaknya dan berbicara dengan mereka 
menggunakan bahasa Indonesia. Selain itu, migrasi penutur Adang ke daerah lain menyebabkan penurunan jumlah penutur Adang dengan cepat. Fokus kajian Haan adalah tata bahasa Adang (fonetik, fonologi, morfologi, dan sintaksis), sehingga tidak dijelaskan secara detil tingkat vitalitas bahasa Adang dan fakor-faktor yang menyebabkannya berpotensi terancam punah.

Selain Haan (2001), bahasa Adang juga pernah diteliti oleh Robinson (2011) dalam proyek HALA (Hawai'I Assessment of Language Access). Bahasa Adang di Pitung Bang, Alor diukur vitalitasnya dengan metode pengukuran psikolinguistik. Hasil penelitian menunjukkan penutur dewasa muda lebih tepat merespons dalam bahasa Indonesia daripada bahasa Adang. Orang tua hampir telah beralih ke bahasa Indonesia dalam mengasuh anak-anaknya. Adang adalah bahasa utama di rumah dan ladang, sedangkan Indonesia sebagai bahasa di gereja dan pasar.

Tulisan ini menggunakan teori vitalitas etnolinguistik untuk mengkaji bahasa Adang yang dituturkan di Adang Buom, yakni wilayah tutur bahasa Adang yang terletak paling dekat dengan Kalabahi, ibu kota Kabupaten Alor. Kajian dibatasi pada vitalitas etnolinguistik bahasa Adang dilihat dari indikator ranah penggunaan bahasa. Jumlah dan kualitas ranah pengguaan bahasa merupakan indikator penting dari vitalitas karena bahasa yang kuat adalah bahasa yang digunakan di banyak ranah atau domain.

\section{LANDASAN TEORI}

Vitalitas bahasa sebagai bidang kajian sosiolinguistik dapat dipahami menggunakan model vitalitas etnolinguistik. Konsep vitalitas etnolinguistik diperkenalkan oleh Giles, Bourhis, dan Taylor (1977) dan didefinisikan sebagai "that which makes a group likely to behave as a distinctive and active collective entity in intergroup situations" (Ehala, 2009; Sosiowati et al., 2019). Menurut konsep ini, bahasa atau komunitas tutur yang tidak atau kurang kuat daya hidupnya lambat laun akan tidak lagi ada sebagai kelompok yang berbeda. Sebaliknya, semakin kuat suatu komunitas tutur, semakin besar kemungkinan ia akan bertahan dan berkembang sebagai entitas linguistik dan kolektif di dalam konteks multibahasa dan antarkelompok (Zaidi, 2016). Komunitas tutur yang memiliki vitalitas etnolinguistik yang tinggi akan bertahan, sedangkan yang vitalitas etnolinguistiknya rendah akan cenderung tergantikan oleh bahasa yang lebih dominan.

Vitalitas etnolinguistik yang dikemukakan oleh Giles et al. mempunyai tiga variabel, yaitu status, demografi, dan dukungan kelembagaan (Yagmur, 2009). Kombinasi dari ketiga 
variable ini membentuk vitalitas dari sebuah kelompok etnolinguistik. Variabel status mencakup status ekonomi, sosial, sosiohistoris, dan bahasa di dalam atau luar komunitas utama. Variabel demografi berkaitan dengan jumlah dan pola distribusi anggota kelompok etnolinguistik di seluruh wilayah regional atau nasional. Variabel demografi juga meliputi angka kelahiran, angka perkawinan campur, dan angka imigrasi dan emigrasi. Adapun dukungan dan kontrol kelembagaan mengacu pada sejauh mana kelompok etnolinguistik menerima dukungan formal dan nonformal di berbagai institusi, media massa, pendidikan, layanan pemerintahan, industri, agama, budaya, dan politik.

Berdasarkan tiga variabel vitalitas etnolinguistik tersebut diasumsikan bahwa semakin banyak status sebuah kelompok etnolinguistik, semakin tinggi vitalitas yang dimilikinya. Kelompok etnolinguistik yang kecenderungan demografinya menguntungkan akan lebih mempunyai vitalitas sebagai kelompok yang berbeda daripada kelompok yang demografinya tidak baik dan tidak kondusif bagi kelangsungan hidup kelompok. Selain itu, vitalitas sebuah kelompok linguistik juga berhubungan dengan derajat penggunaan bahasanya di berbagai institusi pemerintah, tempat ibadah, pusat bisnis, dan lain-lain. Bahasa kelompok linguistik yang digunakan di institusi formal dan informal cenderung memiliki vitalitas yang tinggi.

Vitalitas etnolinguistik yang dikemukakan Giles et al. tidak lepas dari kritik karena indikatornya yang sederhana dan didasarkan pada kriteria kelompok dominan tanpa memperhitungkan faktor-faktor lain. Akibatnya, muncul indikator dan model baru pengukuran vitalitas etnolinguistik yang memperluas tiga indikator teori yang asli, salah satunya adalah Indicators of Ethnolinguistic Vitality (IEV) yang dikemukakan oleh Landweer. Landweer (2016) mengajukan delapan indikator sosiolinguistik yang merupakan dasar pembentuk indikator vitalitas etnolinguistik, yaitu sebagai berikut.

(1) Jarak dan aksesibilitas ke pusat populasi yang memungkinkan penutur kontak dengan bahasa lain. Indikator ini didasari prinsip sosiolinguistik, semakin kecil frekuensi kontak dengan bahasa lain, semakin baik kelangsungan hidup bahasa.

(2) Ranah penggunaan bahasa dalam komunitas tutur: semakin banyak jumlah ranah penggunaan sebuah bahasa, semakin besar penguatan dan pemertahanan penggunaannya.

(3) Frekuensi dan jenis alih kode, didasari prinsip sosiolinguistik, semakin kurang alih kode dalam masyarakat tutur, semakin baik kelangsungan hidup bahasa.

(4) Dinamika populasi dan kelompok: semakin banyak penutur sebuah bahasa, semakin baik kelangsungan hidup bahasanya. 
(5) Jaringan sosial, yakni ada tidaknya jaringan relasi sosial yang mendukung bahasa daerah. Semakin kuat struktur sosial yang menempatkan bahasa daerah menjadi bahasa pilihan, semakin baik kelangsungan hidupnya.

(6) Persepsi sosial komunitas tutur terhadap dirinya mempengaruhi nilai bahasa dan pilihan bahasanya. Semakin besar identitas internal kelompok, pengakuan eksternalnya, dan kekhasan budayanya, semakin baik kelangsungan hidupnya.

(7) Muruah bahasa yang ditunjukkan dengan berbagai cara seperti memilih bahasa daerah yang akan dijadikan media pendidikan atau menentukan bahasa yang akan diajarkan atau dipelajari.

(8) Akses ke basis ekonomi berkaitan dengan ada tidaknya basis ekonomi yang mendukung keberlangsungan penggunaan bahasa. Semakin stabil dan berterima basis ekonomi tempat bahasa daerah menjadi bahasa pilihan, semakin baik kelangsungan hidup bahasa.

Vitalitas etnolinguistik dapat diukur baik secara objektif (statistik aktual) maupun subjektif. Pengukuran secara subjektif dilakukan dengan melihat persepsi dan sikap kelompok etnolinguistik terhadap vitalitasnya sendiri. Dewasa ini, persepsi penutur dari kelompok minoritas tentang vitalitas etnolinguistiknya dianggap lebih penting untuk mempertahankan bahasa dan budayanya. Oleh karena itu, pengukuran yang andal mengenai vitalitas suatu kelompok linguistik paling baik dilakukan dengan menggabungkan informasi objektif yang diperoleh melalui penelitian sekunder dan data subjektif yang didapatkan dari penelitian empiris (Feng \& Adamson, 2013).

Vitalitas bahasa Adang dalam tulisan ini hanya dilihat dari indikator kedua vitalitas etnolinguistik yang dikemukakan oleh Landweer (2016), yakni ranah penggunaan bahasa (dukungan kelembagaan). Pola penggunaan bahasa dalam sebuah komunitas tutur merupakan bagian terpenting untuk dikaji ketika menentukan vitalitas etnolinguistik. Pentingnya penggunaan bahasa dalam mengukur vitalitas mendasari Himmelman mengajukan definisi keterancaman sebagai "languages whose usage domains are presently undergoing a rapid reduction" (Florey, 2011: 44). Menurutnya, bahasa yang vitalitasnya lemah adalah bahasa yang mengalami penurunan jumlah ranah penggunaan dengan cepat. Sebaliknya, bahasa yang vitalitasnya kuat adalah bahasa yang digunakan dalam berbagai latar dan fungsi serta tujuan.

Adams et al.(2012) menyebutkan bahwa ranah dipandang sebagai konteks kelembagaan yang menempatkan satu bahasa lebih sesuai digunakan daripada bahasa lainnya. Ranah juga 
dianggap konstelasi dari berbagai faktor, seperti topik (apa yang dibicarakan), partisipan (siapa pembicara dan lawan bicaranya), dan latar (kapan dan di mana percakapan berlangsung). Grenoble dan Whaley (2006) mengatakan ranah seringkali ditentukan secara geografis, misalnya, bahasa daerah digunakan di komunitas lokal untuk pergaulan di toko atau layanan publik dan untuk tujuan pendidikan. Sementara bahasa lain, bahasa regional atau nasional, digunakan dalam ranah pendidikan, pemerintahan, dan perdagangan di luar komunitas lokal.

Berdasarkan indikator ranah penggunaan bahasa, Landweer (2016) membuat empat skala penilaian vitalitas etnolinguistik. Pertama, bahasa target merupakan bahasa pilihan di ranah rumah dan semua kegiatan kultural dan sosial (skor 3). Kedua, bahasa target merupakan bahasa pilihan di ranah rumah dan dalam kegiatan kultural, tetapi komunikasi dalam kegiatan sosial bercampur dengan lingua franca atau bahasa lain (skor 2). Ketiga, bahasa target menjadi bahasa pilihan di ranah rumah, tetapi di kegiatan kultural dan sosial bercampur dengan lingua franca atau bahasa lain (skor 1). Keempat, bahasa target bercampur dengan lingua franca atau bahasa lain di semua ranah dalam masyarakat itu termasuk di lingkungan rumah (skor 0). Sementara itu, Grenoble dan Whaley (2006) menyebutkan enam tingkat bahasa berdasarkan ranah penggunaannya, yaitu (1) penggunaan universal (2) penggunaan multibahasa, (3) penyusutan ranah, (4) ranah terbatas atau formal, (5) ranah sangat terbatas, dan (6) punah. Wibowo (2016) mendeskripsikan penggunaan universal sebagai penggunaan bahasa secara aktif di semua ranah, sedangkan penggunaan multibahasa mengindikasikan penggunaan satu bahasa dominan atau lebih di ranah resmi dan umum serta penggunaan bahasa non-dominan di ranah pribadi dan lokal. Pada tingkat penyusutan ranah, bahasa lokal semakin jarang digunakan dan pergeseran yang signifikan terjadi karena orang tua berhenti menggunakan bahasa itu di rumah. Pada tingkat selanjutnya, penggunaan bahasa hanya dalam ranah formal dan terbatas seperti upacara, ritual, dan festival. Kemudian penggunaan bahasa pada ranah yang sangat terbatas, yakni hanya digunakan pada kesempatan terbatas dengan penutur yang lanjut usia. Tingkat terakhir adalah punah, ketika bahasa tidak digunakan dalam satu ranah pun.

\section{METODE PENELITIAN}

Kajian ini merupakan penelitian deskriptif yang menganalisis dan menyajikan fakta secara sistematis sehingga mudah untuk dipahami dan disimpulkan (Sudaryana, 2017). Kajian dilakukan dalam beberapa tahap, yaitu penelusuran pustaka, penyebaran kuesioner vitalitas 
bahasa, klasifikasi data, dan analisis data. Data kajian berupa data primer yang dijaring dengan angket dan data sekunder yang diperoleh melalui wawancara dan penelusuran pustaka. Angket yang digunakan adalah kuesioner tertutup dengan dua pilihan jawaban, yaitu ya dan tidak yang telah diuji validitas dan reliabilitasnya. Populasi dalam penelitian ini adalah masyarakat tutur bahasa Adang di Desa Adang Buom, Kecamatan Teluk Mutiara, Kabupaten Alor. Sampel penelitian berjumlah 50 responden yang terdiri atas 28 laki-laki dan 22 perempuan yang merupakan penutur jati bahasa Adang dengan rentang usia $<25$ tahun, $25-50$ tahun, dan $>50$ tahun. Responden tersebut dipilih dengan teknik contoh bertujuan (purposive sampling), yakni pemilihan sampel dengan pertimbangan tertentu. Adapun pengolahan data dilakukan dengan statistik deskriptif yang meliputi penghitungan frekuensi dan persentase. Penghitungan diawali dengan penghitungan frekuensi dan persentase karakterisitik responden dan dilanjutkan dengan frekuensi dan persentase setiap butir pernyataan yang merupakan bagian dari penggunaan bahasa dalam berbagai ranah. Persentase tersebut selanjutnya dihubungkan dengan situasi kebahasaan masyarakat Adang dalam kerangka vitalitas etnolinguistik.

\section{PEMBAHASAN}

Bahasa Adang merupakan salah satu bahasa besar di Alor berdasarkan daerah penyebaran dan luas daerah pemakainya (Adhiti, 2019). Dalam penggolongan itu, bahasa Adang dianggap sebagai bahasa yang sama dengan bahasa Kabola. Daerah tutur Adang, sebagai bahasa yang berbeda dari Kabola, adalah Adang Buom dan Pitung Bang (Otvai). Penutur Adang ditemukan juga di Kenalirang, O’a, Afeng Male (Bang Palol), Eh don, Aimoli, Adang-Kokar, Bot Bag (Bota), Alila, dan Bu Mol. Sementara penutur bahasa Kabola bertempat tinggal di wilayah bagian timur dan timur laut Kalabahi, yaitu di Desa Batu Nata, Padang Tekukur, Jembatan Hitam, Liling Doi, Kebun Kopi, Mai Mol, Mali, Wolatang, dan Me Bung (Haan, 2001).

Hasil wawancara dengan penutur bahasa Adang di Adang Buom menunjukkan penutur bahasa Adang di Pulau Alor ditemukan di Otvai, Aimoli, Alila, Matangbang, Kalabahi Barat, Binongko, Afeng Male, Kenalirang, Kolana, Teluk Kenari, Alaang, dan Kokar. Dilihat dari faktor demografi, persebaran penutur Adang di beberapa desa menunjukkan bahasa ini mempunyai penutur yang cukup banyak di Kabupaten Alor. Perkiraan jumlah penutur Adang cukup variatif, mulai dari 7.000 sampai dengan 31.000 penutur (Robinson, 2011). Adang merupakan bahasa mayoritas di Adang Buom dengan jumlah penduduk desa yang berjumlah 
1.697 jiwa. Proporsi penutur bahasa Adang lebih besar dibandingkan penutur bahasa lain di desa itu. Dengan demikian, bahasa Adang dari sisi demografi mempunyai vitalitas etnolinguistik yang cukup tinggi karena memiliki jumlah penutur Adang yang besar di Alor.

Dilihat dari faktor status, bahasa Adang memiliki sedikit status ekonomi, sosial, dan sosiohistoris. Mayoritas masyarakat Adang dari segi ekonomi bekerja di bidang pertanian yang dapat dikategorikan penghasilan rendah dan menengah. Zaidi (2016) menyatakan kelompok bahasa minoritas yang berpendapatan rendah cenderung akan beralih ke bahasa mayoritas yang memberikan keuntungan ekonomi. Dalam hal ini, bahasa Adang yang secara ekonomi tidak memiliki status digeser oleh bahasa Indonesia yang dominan secara ekonomi. Bahasa yang dominan secara ekonomi dapat memanipulasi kelompok bahasa lain melalui media, pendidikan, dan budaya. Bahasa Adang tidak memiliki status resmi karena dalam konteks Indonesia hanya bahasa Indonesia yang mempunyai status sebagai bahasa nasional. Meskipun demikian, bahasa daerah seperti Adang dilindungi oleh konstitusi. Hanya saja, implementasi peraturan perundang-undangan terkait pelindungan bahasa daerah belum dilakukan secara optimal oleh pemerintah daerah.

Adapun dari faktor dukungan kelembagaan, komunitas Adang dapat dikatakan belum mendapatkan dukungan kelembagaan, baik formal maupun non-formal. Dukungan kelembagaan dapat diinterpretasikan sebagai kekuasaan dalam berbagai manifestasinya, seperti media, administrasi pemerintahan, pelayanan umum, dan pendidikan. Bahasa dan budaya minoritas yang dikecualikan dalam kelembagaan arus utama dipaksa untuk memperoleh dan menyampaikan informasi bukan dengan bahasa mereka sendiri, melainkan dengan bahasa mayoritas. Dalam ranah formal, seperti media masa, pendidikan, dan layanan pemerintahan, bahasa Adang hanya memiliki sedikit dukungan kelembagaan. Meskipun bahasa daerah dapat digunakan sebagai bahasa pengantar pendidikan pada tahap awal pendidikan, tetapi bahasa Adang jarang digunakan. Dalam ranah-ranah formal, bahasa Indonesia cenderung digunakan daripada bahasa Adang. Ketiadaan dukungan kelembagaan dapat menempatkan bahasa Adang pada posisi bahasa dengan vitalitas etnolinguistik yang rendah. Gambaran mengenai penggunaan bahasa Adang dalam ranah formal dan non-formal dapat dilihat pada subbagian berikut.

\section{Penggunaan Bahasa Adang di Adang Buom dalam Berbagai Ranah}

Indikator kedua vitalitas etnolinguistik mengkaji penggunaan bahasa dalam komunitas tutur. Salah satu cara melihat penggunaan bahasa tersebut adalah melalui analisis ranah 
(Landweer, 2016). Jumlah ranah penggunaan bahasa dalam tiap masyarakat tutur bervariasi. Menurut Pauwels (2016), ranah-ranah yang biasa dibicarakan dalam kajian penggunaan bahasa antara lain ranah rumah, persahabatan, ibadah, perkumpulan, dan lembaga, pekerjaan, pendidikan, dan ranah transaksional. Dalam tulisan ini, penggunaan bahasa Adang di Adang Buom dilihat dalam ranah rumah, ibadah, transaksional, pendidikan, dan lembaga.

1) Penggunaan Bahasa Adang di Ranah Rumah

Rumah atau keluarga adalah ranah yang anggotanya berasal dari kelompok etnolinguistik sama. Oleh karena itu, keluarga dengan interlokutornya yang terkait adalah yang paling penting dalam hal pemertahanan bahasa. Jika keluarga tidak lagi mewariskan bahasa ke generasi berikutnya, peluang bahasa itu untuk bertahan hidup berkurang secara drastis (Pauwels, 2016). Dalam banyak studi tentang perilaku multilingualisme, ranah keluarga terbukti sangat penting. Multilingualisme sering dimulai dalam keluarga dan dorongan pelindungan bahasa bergantung padanya (Fishman, 1965). Rumah merupakan ranah yang menjadi benteng terakhir pemertahanan bahasa ibu, karena dalam ranah rumahlah berlangsung komunikasi yang terus menerus antara ayah-ibu, adik-kakak, orang tua-anak, dan anggota keluarga yang lain sehingga proses pewarisan bahasa dari generasi tua ke generasi muda terjadi.

Berdasarkan data kuesioner, jumlah responden yang menyatakan menggunakan bahasa Adang di rumah dalam komunikasi lisan sehari-hari sama banyak dengan yang menyatakan tidak menggunakannya. Sementara dalam komunikasi tulis, yakni dalam surat menyurat dengan keluarga, mayoritas responden mengaku tidak menggunakan bahasa Adang, melainkan bahasa Indonesia. Menurut pengakuan responden, mereka juga menggunakan bahasa Indonesia (Melayu-Alor) di samping bahasa Adang, terutama ketika berkomunikasi dengan anak-anak. Orang tua cenderung untuk memilih mengajarkan dan menuturkan bahasa Indonesia kepada anak-anaknya daripada bahasa Adang.

Penggunaan bahasa Adang di ranah rumah dapat dikatakan masih cenderung dipertahankan oleh kelompok etnolinguistiknya. Meskipun demikian, penggunaan bahasa Adang di ranah rumah tidak ditemukan di semua kelompok usia. Jika melihat penggunaannya pada tiap kelompok usia responden, tampak penggunaan bahasa Adang di rumah cenderung dilakukan oleh penutur yang berada pada kelompok usia di atas 50 tahun (generasi kakeknenek). Sementara, kelompok usia di bawah 25 tahun cenderung tidak menggunakan bahasa Adang di rumah dengan keluarga. Persentase penggunaan bahasa Adang di rumah berdasarkan kelompok usia digambarkan pada diagram 1 berikut. 


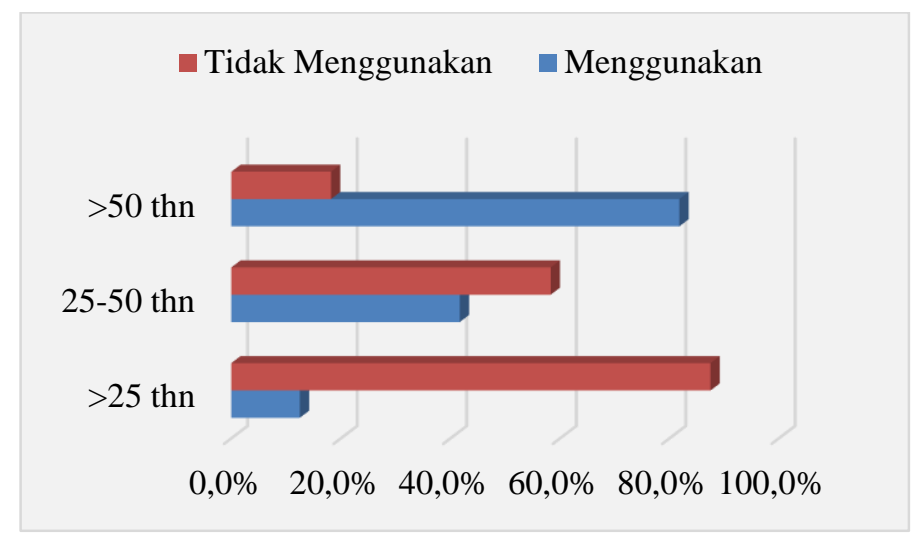

Diagram 1. Penggunaan Bahasa Adang di Ranah Rumah Berdasarkan Kelompok Usia

Kelompok usia di bawah 25 tahun mengaku menggunakan bahasa Indonesia (Melayu-Alor) ketika berbicara dengan keluarganya di rumah. Hal ini tampaknya disebabkan penguasaan bahasa generasi muda Adang di Adang Buom. Satu orang dari semua responden yang berusia di bawah 25 tahun menyatakan menguasai bahasa Adang dengan baik, sedangkan yang lainnya tidak. Mereka yang tidak menguasai bahasa Adang menyatakan bahwa bahasa pertama mereka adalah bahasa Indonesia (Melayu-Alor). Menurut Haan (2001), alasan orang tua Adang mengajarkan anak-anaknya bahasa Indonesia tidak hanya supaya mereka mampu berkomunikasi dengan penutur bahasa yang berbeda, tetapi juga bahasa Indonesia dianggap lebih berprestise dibandingkan bahasa daerah. Hal ini didukung dengan hasil wawancara dengan responden yang menyatakan mereka mengajarkan bahasa Indonesia untuk mempersiapkan proses belajar mereka di sekolah. Responden beranggapan dengan menguasai bahasa Indonesia sejak kecil lebih mudah dalam belajar nanti di sekolah. Ada kekhawatiran di masyarakat apabila anak lebih menguasai bahasa Adang daripada bahasa Indonesia, anak akan sulit memahami pelajaran.

\section{2) Penggunaan Bahasa Adang di Ranah Ibadah}

Ranah ibadah, yang lebih dikenal sebagai ranah keagamaan, terdiri atas kegiatan ibadah pribadi seperti doa, mantera, meditasi, dan kegiatan ibadah publik dan formal. Penggunaan bahasa dalam ranah ibadah merupakan faktor yang cukup penting dalam memperkuat vitalitas bahasa. Apabila sebuah komunitas menjalankan aktivitas keagamaannya dengan menggunakan bahasanya sendiri, kemungkinan besar bahasanya akan dapat dipertahankan dalam waktu yang lama. 
Penggunaan bahasa Adang di ranah keagamaan dalam tulisan ini mencakup ibadah yang dilakukan bersama-sama di gereja/masjid dan ibadah yang dilakukan sendirian berupa doa. Data BPS (2019) menunjukkan mayoritas penduduk Adang Buom menganut agama Kristen Protestan, yakni sekitar 2,05\% dari total jumlah penduduk. Selanjutnya, ada penganut agama Islam sebesar 1,18\% dan Katolik 0,03\%. Dalam kegiatan keagamaan di gereja dan masjid, sebagian responden menyatakan menggunakan bahasa Indonesia, sedangkan sebagian lainnya menggunakan bahasa Adang. Menurut pengakuan responden, ibadah di gereja dan masjid menggunakan bahasa Indonesia karena jamaah yang hadir berasal dari latar kebahasaan yang berbeda, bukan hanya penutur bahasa Adang. Sementara dalam ranah ibadah berdoa sendiri, mayoritas responden mengaku tidak menggunakan bahasa Adang. Mereka cenderung menggunakan bahasa Indonesia (Melayu-Alor).

Tabel 1.

Penggunaan Bahasa Adang di Ranah Ibadah

\begin{tabular}{clllc}
\hline \multirow{2}{*}{ No. } & \multicolumn{1}{c}{ Konteks } & Jawaban & F & P \\
\hline \multirow{2}{*}{1} & $\begin{array}{l}\text { Ibadah keagamaan di } \\
\text { gereja/mesjid }\end{array}$ & Tidak & 27 & $54 \%$ \\
\cline { 3 - 5 } & & Ya & 23 & $46 \%$ \\
\cline { 3 - 5 } & Botal & 50 & $100 \%$ \\
\hline \multirow{2}{*}{2} & Berdoa sendiri & Tidak & 34 & $68 \%$ \\
\cline { 3 - 5 } & & Ya & 16 & $32 \%$ \\
\cline { 3 - 5 } & & Total & 50 & $100 \%$ \\
\hline
\end{tabular}

Preferensi penggunaan bahasa daerah dalam ibadah keagamaan yang formal dan terlembaga biasanya kurang jelas. Namun, dalam doa yang bersifat privat, banyak penutur yang tetap menggunakan bahasa daerahnya (Pauwels, 2016). Hal ini ditemukan juga dalam masyarakat Adang di Adang Buom seperti ditunjukkan pada Tabel 1. Pada saat ibadah formal di gereja/ masjid, bahasa yang digunakan adalah bahasa Indonesia (Melayu-Alor) dan juga bahasa Adang. Akan tetapi, kecenderungan penggunaan bahasa daerah dalam doa yang bersifat privat tidak ditemukan. Saat berdoa sendiri kecenderungannya tidak menggunakan bahasa Adang. Responden yang menyatakan menggunakan bahasa Adang ketika berdoa sendiri, yakni sebesar 32\% adalah sebagian dari kelompok usia 25-50 tahun dan di atas 50 tahun. Tampak bahwa preferensi penggunaan bahasa Adang dalam doa hanya dilakukan oleh sebagian penutur dewasa menengah dan dewasa akhir. 
3) Penggunaan Bahasa Adang di Ranah Transaksional

Ranah transaksional yang dimaksudkan di sini adalah penggunaan bahasa Adang oleh penutur ketika menjual atau membeli barang di pasar tradisional dan ketika menulis surat perjanjian jual beli atau sewa.

Tabel 2.

Penggunaan Bahasa Adang di Pasar

\begin{tabular}{cclccc}
\hline \multirow{2}{*}{ No. } & \multicolumn{1}{c}{ Konteks } & Jawaban & $\mathrm{F}$ & $\mathrm{P}$ \\
\hline \multirow{2}{*}{1} & $\begin{array}{l}\text { Transaksi jual beli di } \\
\text { pasar }\end{array}$ & Tidak & 25 & $50 \%$ \\
\cline { 3 - 5 } & & Ya & 25 & $50 \%$ \\
\cline { 3 - 5 } 2 & $\begin{array}{l}\text { Perjanjian jual } \\
\text { atau sewa }\end{array}$ & beli & 50 & $100 \%$ \\
\hline \multirow{2}{*}{2} & & Tidak & 49 & $98 \%$ \\
\cline { 3 - 5 } & & Ya & 1 & $2 \%$ \\
\hline
\end{tabular}

Berdasarkan Tabel 2, sebesar 50\% responden menyatakan tidak menggunakan bahasa Adang dalam transaksi jual beli di pasar, sedangkan 50\% responden lainnya menyatakan menggunakannya. Dengan demikian, dapat dikatakan bahwa bahasa yang digunakan pada saat jual beli di pasar adalah bahasa Adang, di samping adanya kecenderungan penggunaan bahasa Indonesia (Melayu-Alor). Akan tetapi, dalam surat perjanjian jual beli atau sewa, hampir seluruh responden menyatakan tidak menggunakan bahasa Adang. Bahasa yang digunakan adalah bahasa Indonesia. Kecenderungan penggunaan bahasa Indonesia (Melayu Alor) di ranah transaksional tampaknya disebabkan keragaman latar belakang kebahasaan penjual atau pembeli. Pusat perdagangan di Adang Buom hanya berupa kios/ warung/ toko, dan tidak terdapat pasar tradisional. Pasar tradisional (pasar mingguan) berada di Kalabahi Kota, Kalabahi Timur, Nusa Kenari, dan Fanating (BPS, 2019). Jika transaksi jual beli masih dalam komunitas Adang Buom, bahasa Adang tentu digunakan. Akan tetapi, di luar komunitas Adang Buom, misalnya di pasar mingguan Kalabahi Kota, bahasa Indonesia (Melayu-Alor) cenderung lebih banyak digunakan.

\section{4) Penggunaan Bahasa Adang di Ranah Pendidikan}

Penggunaan bahasa daerah dalam ranah pendidikan ditandai oleh keragaman yang sangat besar. Keragaman itu merupakan hasil dari banyak faktor, termasuk latar belakang komunitas, jenis sekolah dan dasar linguistik negara (monolingual atau bi/ multilingual). Hal ini selanjutnya dipengaruhi oleh keberadaan dan/ atau dukungan kebijakan nasional, regional dan internasional tentang pendidikan bahasa ibu (Pauwels, 2016). Pendidikan merupakan ranah penting penggunaan bahasa. Pada wilayah yang menyelenggarakan sistem pendidikan 
secara nasional atau regional, bahasa Pendidikan menjadi penentu utama penggunaan bahasa di ranah-ranah lain (Grenoble \& Whaley, 2006).

Dalam konteks Indonesia, bahasa pengantar pendidikan di sekolah adalah bahasa Indonesia sebagaimana disebutkan dalam Undang-undang Nomor 24 Tahun 2009 Pasal 29 ayat (1). Meskipun demikian, bahasa daerah dapat digunakan sebagai bahasa pengantar pada tahap awal pendidikan serta dalam penyampaian pengetahuan atau keterampilan tertentu (UU Nomor 20 Taahun 2003, Bab VII, Pasal 33, Ayat 2). Dalam hal ini bahasa daerah mempunyai fungsi pendukung atau pelengkap bahasa Indonesia sebagai pengantar utama dalam sistem pendidikan nasional.

Berkenaan dengan bahasa Adang, bahasa ini cenderung tidak digunakan sebagai bahasa pengantar pada saat guru mengajar, baik di kelas-kelas rendah maupun kelas-kelas tinggi. Demikian pula dalam interaksi dan komunikasi antara guru/ kepala sekolah dan siswa/ wali murid yang berasal dari etnis Adang. Bahasa Adang cenderung tidak digunakan di lingkungan sekolah. Bahasa yang digunakan sebagai alat komunikasi adalah bahasa Indonesia (MelayuAlor). Hal ini dapat dilihat pada tabel 3 berikut.

Tabel 3.

Penggunaan Bahasa Adang di Sekolah

\begin{tabular}{cclcc}
\hline \multirow{2}{*}{ No. } & \multicolumn{1}{c}{ Konteks } & Jawaban & $\mathrm{F}$ & $\mathrm{P}$ \\
\hline \multirow{3}{*}{1} & \multirow{2}{*}{\begin{tabular}{l} 
Guru mengajar di sekolah \\
\cline { 3 - 5 }
\end{tabular}} & Tidak & 45 & $90 \%$ \\
\cline { 3 - 5 } & & Ya & 5 & $10 \%$ \\
\cline { 3 - 5 } & \multirow{2}{*}{$\begin{array}{l}\text { Guru/kepala sekolah berbicara } \\
\text { dengan etnis Adang }\end{array}$} & Total & 50 & $100 \%$ \\
\cline { 3 - 5 } & & Tidak & 39 & $78 \%$ \\
\cline { 2 - 5 } & & Ta & 11 & $22 \%$ \\
\hline
\end{tabular}

Penggunaan bahasa dalam ranah pendidikan dapat dilihat dalam konteks pembelajaran di kelas maupun komunikasi di luar kelas. Dalam konteks pembelajaran di kelas, baik dalam kelas rendah maupun kelas tinggi sebanyak $90 \%$ proses pembelajaran menggunakan bahasa Indonesia (Melayu-Alor), sedangkan 10\% menggunakan bahasa Adang. Kecenderungan guru menggunakan bahasa Indonesia (Melayu-Alor) dalam proses pembelajaran dilatarbelakangi oleh tiga hal, yakni siswa yang beragam latar belakang bahasa, guru yang tidak berasal dari etnis Adang, dan materi/ bahan ajar yang semuanya berbahasa Indonesia. Apabila guru/ kepala sekolah berbicara dengan etnis Adang, baik dengan sesama guru/ kepala sekolah maupun siswa etnis Adang sebagian besar menggunakan bahasa Indonesia. Hal ini terlihat dari Tabel 3. Terlihat 78\% menggunakan bahasa Indonesia (Melayu-Alor), sedangkan 22\% mennggunakan bahasa Adang. Berdasarkan wawancara, hal ini terjadi karena sebagain besar 
menganggap bahwa sekolah adalah tempat formal, jadi sebaiknya menggunakan bahasa Indonesia (Melayu-Alor). Mereka hanya menggunakan bahasa Adang apabila berhubungan dengan hal-hal pribadi pada kegiatan nonformal.

SD GMIT 005 Adang merupakan satu-satunya sekolah yang terdapat di Adang Buom, sehingga anak-anak Adang Buom yang akan melanjutkan ke sekolah menengah pertama (SMP) dan sekolah menengah atas (SMA) harus bersekolah di luar komunitasnya. SMP dan SMA terdekat dari Adang Buom terdapat di Kalabahi Barat, Binongko, dan Kalabahi Kota. Bersekolah di luar komunitas Adang tentu mengharuskan penggunaan bahasa yang dapat digunakan untuk berkomunikasi antaretnis yang berbeda bahasa.

Apabila bahasa daerah menjadi bagian dari proses pendidikan formal, biasanya bahasa itu akan mempertahankan tingkat vitalitas yang lebih tinggi. Sebaliknya, apabila pelaksanaan pendidikan di sekolah wajib dilakukan dalam bahasa nasional, penggunaan bahasa daerah dapat dipastikan menurun. Bahasa Adang yang tidak menjadi bagian dalam proses pendidikan formal lambat laun akan kehilangan ranah penggunaan yang dapat menyebabkan bahasa ini berpotensi terancam punah.

\section{5) Penggunaan Bahasa Adang di Ranah Institusi}

Ranah institusi yang dimaksudkan di sini berkaitan dengan penggunaan bahasa Adang di pusat layanan kesehatan seperti puskesmas atau rumah sakit dan pusat pemerintahan seperti kantor desa/ kelurahan dan kantor kecamatan.

Tabel 4.

Penggunaan Bahasa Adang di Ranah Pemerintahan

\begin{tabular}{cclccc}
\hline \multicolumn{5}{c}{ Konggunaan Bahasa Adang di Ranah Pemerintahan } \\
\hline \multirow{2}{*}{1} & \multicolumn{2}{c}{ Konteks } & Jawaban & F & P \\
\hline \multirow{2}{*}{$\begin{array}{l}\text { Berbicara } \\
\text { kesehatan }\end{array}$} & dengan & petugas & Tidak & 48 & $96 \%$ \\
\cline { 3 - 5 } & & Ya & 2 & $4 \%$ \\
\cline { 3 - 5 } 2 & \multirow{2}{*}{$\begin{array}{l}\text { Berbicara dengan aparat desa } \\
\text { atau kecamatan }\end{array}$} & Total & 50 & $100 \%$ \\
\cline { 3 - 5 } & & Tidak & 26 & $52 \%$ \\
\cline { 3 - 5 } & & Yatal & 24 & $48 \%$ \\
\hline
\end{tabular}

Tabel 4 di atas memperlihatkan penggunaan bahasa Adang di pusat kesehatan dan pemerintahan. Sebagian besar responden cenderung tidak menggunakan bahasa Adang ketika berbicara dengan petugas kesehatan di pusat layanan kesehatan, melainkan menggunakan bahasa Indonesia (Melayu-Alor), yaitu sebesar 94\%. Hanya sebagian kecil responden, yaitu sebanyak 4\%, menyatakan menggunakan bahasa Adang. Menurut data BPS Kabupaten Alor (2019), fasilitas kesehatan di Adang Buom hanya posyandu, sedangkan puskesmas dan rumah 
sakit berada di Kalabahi Barat, Kalabahi Kota, dan Welai Timur. Demikian pula dengan tenaga kesehatan (dokter, perawat, bidan) tidak ditemukan di Adang Buom. Oleh karena itu, masyarakat Adang mendapatkan layanan kesehatan di pusat-pusat kesehatan yang berada di luar komunitasnya. Hal ini tentu memberikan peluang terjadinya kontak dengan penutur bahasa yang berbeda.

Sementara itu, ketika berbicara dengan aparat desa atau kecamatan, sebanyak 52\% responden menyatakan tidak menggunakan bahasa Adang dan $48 \%$ menyatakan menggunakan bahasa Adang. Menurut responden, mereka akan berbicara dengan bahasa Adang jika aparat desa/ kecamatan dan tenaga kesehatan juga merupakan penutur Adang. Akan tetapi, topik pembicaraannya bukan hal yang berkaitan dengan urusan pemerintahan, melainkan urusan pribadi.

Penggunaan bahasa Adang dalam lima ranah sebelumnya memberikan gambaran bahwa bahasa Adang dalam komunitas Adang Buom mulai mengalami penyusutan ranah. Ranah penggunaan bahasa Adang sudah semakin sedikit. Ranah rumah yang merupakan benteng terakhir pemertahanan bahasa sudah mulai dimasuki oleh penggunaan bahasa Indonesia (Melayu-Alor). Orang tua mulai menggunakan bahasa Indonesia (Melayu-Alor) di samping bahasa Adang di dalam komunikasi lisan sehari-hari dengan anak-anaknya. Transmisi bahasa Adang antargenerasi tampaknya mulai berkurang sehingga anak-anak menjadi semi-penutur bahasa daerahnya. Orang tua dan anggota komunitas Adang di Adang Buom cenderung menjadi dwibahasawan atau bahkan multibahasawan yang memahami dan menuturkan dua bahasa atau lebih: bahasa Adang, Melayu-Alor, dan bahasa Indonesia. Situasi kebahasaan dalam masyarakat Adang ini sejalan dengan temuan Nazaruddin (2013) dalam penelitiannya tentang bahasa Oirata di Pulau Kisar, yang menunjukkan bahwa masyarakat Oirata menggunakan bahasa Oirata dalam komunikasi dengan anggota keluarga mereka, bahasa Melayu Ambon dengan orang non-Oirata, dan menggunakan bahasa Indonesia sebagai bahasa pengantar di sekolah. Gejala dwibahasa/ multibahasa di kalangan penutur inilah yang dapat mendorong terjadinya pergeseran penggunaan bahasa. Dengan demikian berdasarkan indikator kedua vitalitas etnolinguitik (IEV), bahasa Adang di Adang Buom dapat dikatakan berada pada skala keempat, yakni penggunaan bahasa Adang bersamaan dengan lingua franca (Melayu-Alor dan Indonesia) di berbagai ranah, termasuk di ranah lingkungan rumah.

Penggunaan bahasa tertentu di ranah tertentu juga tidak terlepas dari motivasi yang dimiliki oleh penutur. Motivasi itu dapat berupa motivasi komunikatif, ekonomi (pekerjaan, perdagangan, jaringan relasi), identitas sosial (muruah kelompok, solidaritas, jarak), kuasa 
dan muruah bahasa (bentuk bahasa tinggi dan rendah), politik dan nasionalis, serta motivasi religius (Karan, 2011). Dalam konteks masyarakat Adang di Adang Buom, motivasi yang mendorong penutur untuk tidak menggunakan bahasa daerahnya di ranah tertentu, tetapi menggunakan bahasa Indonesia (Melayu-Alor) tampaknya bersifat komunikatif, ekonomi, prestisius, dan religius.

Motivasi komunikatif mendorong penutur Adang menggunakan bahasa Indonesia (Melayu-Alor) untuk memudahkan komunikasi dengan lawan tuturnya yang berbeda bahasa. Motivasi ekonomi, khususnya yang berkaitan dengan perdagangan, bahasa Indonesia (Melayu-Alor) dipilih untuk memfasilitasi transaksi jual beli. Motivasi prestisius pemilihan bahasa Indonesia dalam komunikasi sehari-hari karena adanya anggapan bahasa Indonesia lebih memiliki muruah daripada bahasa daerah. Selanjutnya, motivasi religius yang juga mempengaruhi pilihan bahasa penutur Adang di ranah ibadah. Penutur Adang yang beragama Islam cenderung akan memilih berdoa bukan dengan bahasa Adang karena Islam dilekatkan dengan bahasa Arab sehingga doa-doa menggunakan bahasa Arab. Motivasi penutur Adang untuk menggunakan bahasa Indonesia relevan dengan apa yang disebutkan oleh Haan (2001) dan Sahril (2018) dalam penelitiannya bahwa alasan komunikatif dan prestisius mendorong orang tua menggunakan dan mengajarkan bahasa Indonesia kepada anak-anaknya.

\section{PENUTUP}

Peran komunitas tutur sangat penting dalam penentuan keberlangsungan hidup bahasanya; apakah dipertahankan ataukah diabaikan. Sikap penutur terhadap bahasanya akan memengaruhi pilihan bahasa yang mereka gunakan di berbagai ranah pertuturan, yang pada akhirnya mempengaruhi juga proses pewarisan antargenerasi bahasa itu. Komunitas Adang di Adang Buom tampaknya mulai kehilangan ranah penggunaan bahasa daerahnya. Ranah-ranah pribadi penggunaan bahasa Adang mulai dirembesi penggunaan bahasa Indonesia (MelayuAlor).

Penguasaan bahasa Adang generasi muda sebagai penanda kuatnya daya hidup sebuah bahasa cenderung tidak menguasai bahasa komunitasnya dengan baik. Penggunaan bahasa Adang di ranah rumah, ibadah, transaksi, lembaga pemerintahan, dan kesehatan bersamaan dengan penggunaan bahasa Indonesia (Melayu-Alor). Oleh karena itu, penguatan kembali penggunaan bahasa Adang di berbagai ranah tuturan, khususnya ranah rumah dan ranah pribadi lainnya, perlu dilakukan kembali oleh penutur Adang di Adang Buom. Jika tidak, 
lambat laun bahasa Adang akan benar-benar kehilangan ranah dan menjadi bahasa yang terancam punah.

\section{DAFTAR PUSTAKA}

Adams, Y., Matu, peter M., \& Ongarora, david O. (2012). Language Use and Choice: A Case Study of Kinubi in Kibera, Kenya. International Journal of Humanities and Social Science, 2(4), 99104.

Adhiti, I. A. I. (2019). Etimon Proto Austronesia (PAN) pada Bahasa Alores di Pulau Alor Nusa Tenggara Timur. Widyadari, 20(1), 145-157. https://doi.org/10.5281/-zenodo.2655024

Adhiti, I. A. I. (2020). Sinonimi Bahasa Kabola dan Bahasa Hamap di Pualu Alor, Nusa Tenggara Timur: Suatu Kajian Deskriptif Analisis. KULTURISTIK: Jurnal Bahasa Dan Budaya, 4(2), 60-68. https://doi.org/10.22225/kulturistik.4.2.1896

Berimau, I. F. (2018). Studi Mengenai Cara-Cara Jemaat Adang Buom Mewariskan Memori Kolektif tentang Mitos Adang dan Tuandiri serta Manfaatnya bagi Perilaku Sehari-Hari. Universitas kristen Satya Wacana.

BPS. (2019). Kecamatan Teluk Mutiara dalam Angka 2019. BPS Kabupaten Alor.

Ehala, M. (2009). Ethnolinguistic Vitality and Minority Education. The Journal of Linguistic and Intercultural Education, 2(1), 37-48. https://doi.org/10.29302/jolie.2009.2.1.3

Feng, A., \& Adamson, B. (2013). The Study of Ethnolinguitic Vitality: Technical Paper, Models of Trilingual Education in Ethnic Minority Regions of China Project. In The Education University of Hong Kong. https://www.eduhk.hk/include_n/getrichfile.php?key=6148c1517703b52c30736f797366e845\&secid=53239\&filename=triling/Technical_P aper_2_Ethnolinguistic_Vitality.pdf

Grenoble, L. A., \& Whaley, L. J. (2006). Saving Languages An Introduction to Language Revitalization. Cambridge University Press. https://doi.org/10.1017/CBO9780511615931

Haan, J. W. (2001). The Grammar of Adang: A Papuan Language Spoken on the Island of Alor East Nusa Tenggara - Indonesia [University of Sydney]. http://hdl.handle.net-/2123/6413

Hirsh, D. (2013). Endangered Languages, Knowledge System and Belief System. Peter Lang. https://doi.org/10.3726/978-3-0351-0503-2

Karan, M. E. (2011). Understanding and Forecasting Ethnolinguistic Vitality. Journal of Multilingual $\begin{array}{llll}\text { and } \quad \text { Multicultural } & \text { Development, }\end{array}$ https://doi.org/10.1080/01434632.2010.541916

Landweer, M. L. (2016). Indicators of Ethnolinguistic Vitality Review and Score Sheet. GIALens, $10(1), 1-14$.

Nazarudin, N. (2013). Bahasa Oirata, Pulau Kisar. Ranah: Jurnal Kajian Bahasa, 2(1), 1. https://doi.org/10.26499/rnh.v2i1.51

Pauwels, A. (2016). Language Maintenance and Shift. Cambridge Unversity Press. https://doi.org/10.1017/CBO9781107338869

Probonegoro, N. K. (2008). The Ethnolinguistic Identity of the Hamap People in Change. Journal of Indonesian Social Sciences and Humanities, 1(1), 193-206. https://doi.org/10.14203/issh.v1i1.14

Robinson, L. C. (2011). A psycholinguistic Assessment of Language Change in Eastern Indonesia: Evidence from the HALA Project. In Keeping Languages Alive: Documentation, Pedagogy, and Revitalization (pp. 16-28). Cambridge University Press. https://doi.org/10.1017/CBO9781139245890.003

Sahril, N. (2018). Pergeseran Bahasa Daerah Pada Anak-Anak di Kuala Tanjung Sumatra Utara. Ranah: Jurnal Kajian Bahasa, 7(2), 210. https://doi.org/10.26499/rnh.v7i2.571

Sosiowati, I., Arka, I., Aryawibawa, I., \& Widiastuti, N. (2019). Domain Change and Ethnolinguistic Vitality: Evidence from the Fishing Lexicon of Loloan Malay. Language Documentation \& Conservation, 13, 586-617.

Tondo, F. H. (2007). Bahasa Hamap dalam Masyarakat Multilingual di Alor dan Upaya 
Pelestariannya. Masyarakat Dan Budaya, 9(1), 105-122.

Wibowo, S. F. (2016). Pemetaan Vitalitas Bahasa-Bahasa Daerah Di Bengkulu: Pentingnya Tolok Ukur Derajat Kepunahan Bagi Pelindungan Bahasa Daerah. Ranah: Jurnal Kajian Bahasa, 5(2), 139-151. ttps://doi.org/10.26499/rnh.v5i2.149

Yagmur, K. (2009). Language Use and Ethnolinguistic Vitality of Turkish Compared with the Dutch in the Netherlands. Journal of Multilingual and Multicultural Development, 1-15. https://doi.org/10.1080/01434630802369445

Zaidi, A. (2016). Ethnolinguistic vitality of Punjabi in Pakistan: A GIDS approach. Linguistics and Literature Review, 02(01), 01-16. https://doi.org/10.32350/llr.21.01 